\title{
Japanese Culture through Videogames
}

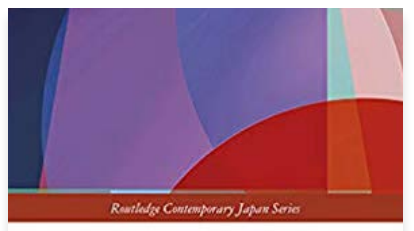

JAPANESE CULTURE THROUGH VIDEOGAMES

Rachacl Hurchinson

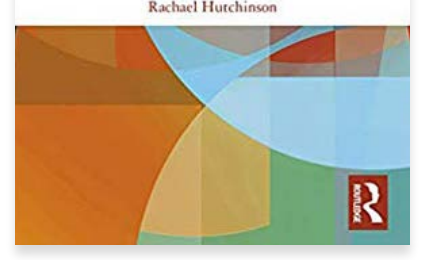

\section{RACHAEL HUTCHINSON.}

Routledge (London and New York), 2019.

294 pages.

ISBN 9780367111380.

https://doi.org/10.4324/9780429025006.

Reviewed by

Gawain Lucian Lax

Monash University

https://orcid.org/0000-0003-1297-1042

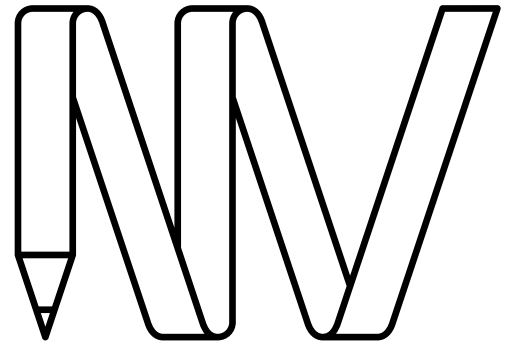

NEW

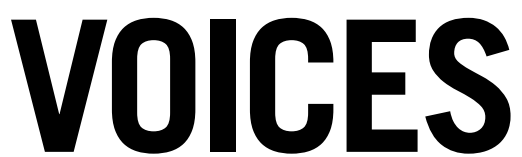

IN JAPANESE STUDIES

\section{KEYWORDS}

anime; contemporary; game media; popular culture

A s evident from Rachael Hutchinson's self-description in the introduction of Japanese Culture Through Videogames, in which she names herself both "a gamer and an academic in the field of Japanese Studies" (8), the aim of this monograph is to bridge the gap between the fields of Japanese and game studies. Hutchinson notes that, while many of the games she analyses have already been studied at length, Western analysts have long neglected to read these texts as "games about Japan" (11). Her argument is that these two fields have much to offer each other, and should both place more of a focus on games as Japanese texts. Hutchinson has written on this subject before, noting in the acknowledgments that three chapters build on her previous work, and a number of her other publications appear in the book's bibliography.

After an introduction, the book is divided into three sections of three chapters each. The first part, "Japanese Culture as Playable Object", is concerned largely with how Japanese games package Japan for popular consumption. This section begins with a chapter on Katamari Damacy [2004], a game about rolling objects into an increasingly large ball, set against backdrops such as a traditional Japanese home and a rural town. Katamari, unlike many other Japanese pop-cultural exports, does not attempt to minimise its Japaneseness,

\section{JAPANFOUNDATION \& BRINGING JAPAN TO YOU \\ To link to this article: https://doi.org/10.21159/nvjs.12.r-01}

\section{ISSN 2205-3166}

New Voices in Japanese Studies is an interdisciplinary, peer-reviewed journal showcasing the work of emerging scholars with ties to Australia or New Zealand and research interests in Japan.

All articles can be downloaded free at newvoices.org.au

(c) The Japan Foundation, Sydney and Gawain Lucian Lax, 2020.

\section{(c) $\underset{\mathrm{BY}}{\mathrm{BY}}(\mathbf{\mathrm { NC }})$}

This work is licensed under a Creative Commons Attribution-NonCommercialNoDerivatives 4.0 International License. 
which Hutchinson plays off against Iwabuchi's (2004) arguments about cultural odourlessness and the idea that Japanese popular media markets itself by deliberately obscuring its origins. Rather, Katamari revels in particularly Japanese aesthetics of space and culture, marketing "Japan itself as a cultural object" for consumption both locally and abroad (43). The next chapter shifts focus from space to time and looks at Ökami [2006], a game that packages Japan's past through a narrative that riffs on the country's mythology. Yet, Hutchinson argues, any framing of the past is inherently ideological—and by framing Japan through its mythology, the game perpetuates a myth of its own that the country is a "homogenous, easily commodified nation" (66). The first section concludes with a chapter on a range of fighting game series, mainly Street Fighter [1987-2020] and Tekken [1994-2017], to investigate how the Japanese 'self' is constructed against a (nearly always American) 'other'.

The book's second section, "Ideology and Critique in Japanese Games", turns more specifically to how social issues in Japan have been explored through games. The fourth chapter looks at family structures in the Japanese roleplaying game (JRPG) genre, and particularly at how the common trope of protagonists with dead or absent parents stems from the real-world breakdown of the family unit. The fifth chapter follows on by focusing on the JRPG series Final Fantasy [1987-2020], noting how it comments on nuclear issues through allegories about dangerous technology. Unfortunately, this chapter cuts off shortly after raising its most interesting point: that the nature of Japan's nuclear anxieties has shifted since the 2011 Fukushima disaster, from centring on "the American other to the Japanese Self" (147), and that the nuclear allegories in Final Fantasy have also shifted accordingly. The third chapter in this section extends the theme of nuclear discourse, but marries it with a discussion about bioethics and genetic manipulation, playing various Final Fantasy titles against games from the Metal Gear [1987-2018], Tekken and Resident Evil [1996-2020] series. Hutchinson's argument here is that both issues centre around anxieties about the nuclear-"genetic manipulation in the human body, and the unleashing of nuclear power"-and therefore draw on themes such as ethics and responsibility (173).

In the book's final section, "History, Memory, and Re-Imagining War", Hutchinson turns to the way that Japanese games contribute to discourses around war, violence and colonialism. The seventh chapter is perhaps the book's most convincing, and certainly the one which ties together its arguments most satisfyingly. It compares Japanese games about war to Western games about war, pointing out key differences in both genre and thematic treatment. While Western games about war tend to be gritty, realistic shooters set during or after the twentieth century, Japanese games about war tend to both belong to other genres, and take place centuries in the past.

Hutchinson argues that these marked differences stem from the very different outcomes for Japan and the Allies in World War II, rendering the theme of modern warfare "extremely problematic" in the Japanese context (189). The book's last two chapters examine, respectively, the legacy of Hiroshima in the Metal Gear series, and the way that Japan's colonial history (especially in regard to Korea) is obscured in a number of titles. 
The book has a wide scope, but it also has a number of shortcomings, more significantly on the game studies side. Perhaps most prominently, Hutchinson chooses to focus almost exclusively on big-name Japanese games, which have all been discussed at length in both Japan and the West, in game studies and journalism, since their releases. This is especially significant since many of Hutchinson's key case studies-most prominently, Metal Gear Solid [1998], Final Fantasy VII [1997] and a slew of fighting game series such as Street Fighter-are not new games, but date from the 1990s. Although there can certainly be value in continuing to approach such staples of the videogame canon over two decades later, Hutchinson's analysis of these titles often does not feel incisive enough to justify re-treading such well-worn ground, regardless of the author's new perspective from Japanese studies.

This shortcoming is further enhanced by the nature of Hutchinson's game studies analysis. In her first chapter, the author situates her analysis within the ludology versus narratology debate in game studies. One of her early footnotes sums up the argument as taking place between narratologists, who privilege "a narrative reading of games", and ludologists, who privilege "the gameplay aspects of an algorithmic text", and concludes that it is now broadly accepted that narrative and gameplay should be studied together (43). Although this is an important piece of context for this book as a game studies work, Hutchinson does not treat these aspects equally in her analysis. I am no ludologist, but the arguments presented in this book often skew disproportionately towards the narratological, and the arguments about how these games play (and feel to play) are both fewer and less convincing than the narrative ones.

For these reasons, this book is likely to prove more useful to scholars of Japanese studies than to scholars interested in games. However, it should prove interesting reading for anyone curious about how Japanese games, despite being marketed to a worldwide audience, are nevertheless crucial artistic sites for discourse around social and political issues affecting Japan.

\section{REFERENCES}

Iwabuchi, K. 2004. "How 'Japanese' is Pokémon?” In Pikachu's Global Adventure: The Rise and Fall of Pokémon, edited by J. Tobin, 53-79. Durham and London: Duke University Press. https://doi-org /10.1215/9780822385813-004. 